\title{
Diversity of Surface Layers in L-forms of Proteus mirabilis
}

\author{
By P. H. HOFSCHNEIDER \\ Max-Planck-Institut für Biochemie, München, Germany \\ AND H. H. MARTIN \\ Institut für Mikrobiologie, Technische Hochschule, Darmstadt, Germany
}

(Accepted for publication I September 1967)

SUMMARY

The structure of surface layers of the bacterial form and different types of the L-form of Proteus mirabilis was studied by electron microscopy of thinsectioned organisms. Morphological data confirm the distinction between the cell wall-less protoplast-L-form and the wall-containing spheroplast-L-form. Organisms of the protoplast-L-form have only one surface-integument, presumably the cytoplasmic membrane. These forms never revert to the bacterial form. The spheroplast-L-form comprises reversible forms (unstable-spheroplast-L-form) as well as non-reverting strains (stable spheroplast-L-form). In both spheroplast-L-forms two surface integuments are always present: a cytoplasmic membrane and a superposed cell wall. In sections of isolated cell walls of normal Proteus bacteria and in wall material spontaneously dissociating from damaged cell walls of spheroplast-L-forms the triple-layered 'unit membrane' is a prominent feature. Thin sections of isolated cell wall lipopolysaccharide identify the unit membrane as a specific structure of this polymer. The thickness of the murein (syn. mucopeptide, mucopolymer) in isolated murein layers ('murein sacculi', Weidel \& Pelzer, I964) from cell walls of normal Proteus bacteria was found to be approximately $20-25 \AA$.

\section{INTRODUCTION}

The task of describing and defining bacterial L-forms has always been a problematic and perplexing one. The organisms are best known for their negative qualities, and their elusive nature is strikingly characterized in their description as: 'The stable growth which consists of soft, protoplasmic elements without defined morphology, which no longer possesses rigid, bacterial forms nor reverts to them...' (Klieneberger-Nobel, 1960). Much remains to be learned about their origin. There is, however, general agreement that the aberrant L-form morphology and the lack of solid cell envelopes is due to functional deficiencies in the biosynthetic apparatus of the bacterial cell wall. The comparative study of surface structures in L-forms and their original bacterial forms is therefore of considerable interest, since it may provide information on the functions and requirements of the morphogenetic apparatus which establishes specific shape and stability in the normal bacterial cell wall. Early work on the penicillin-induced L-forms of Proteus mirabilis indicated that the L-form character may be related to very different levels of cell wall damage. These observations are now best understood on the basis of cell-wall models which have been derived from extensive analytical and electron microscopical work on cell walls of Escherichia coli and 
$P$. mirabilis. These cell walls are constructed on the foundation of a cell-shaped murein (syn. mucopeptide, mucopolymer) layer ('murein sacculus', Weidel \& Pelzer, 1964). Two other macromolecular wall components are also present in large amounts: lipopolysaccharide (LPS), and lipoprotein. These polymers are anchored to the murein sacculus to form an intricate mosaic pattern of functional surface sites (antigens, bacteriophage receptors) whose structural details are still largely unknown (Weidel, 1958; Weidel, Frank \& Martin, 1960; Martin \& Frank, 1962; Weidel \& Pelzer, 1964; Martin, 1964). The stable (= irreversible) L-form of $P$. mirabilis was found to lack both murein components and bacteriophage receptors and thus, like protoplasts of Gram-positive bacteria, seemed to have no cell wall (Kandler \& Zehender, 1957; Taubeneck, Böhme \& Schumann, 1958; Taubeneck, 196r). In contrast, the unstable ( = reversible) L-form contained murein as well as phage receptors (Kandler, Hund \& Zehender, 1958; Taubeneck et al. 1958). Thin sections of the unstable L-forms revealed the presence of cell walls, and this suggested a similarity of these organisms with the penicillin- or lysozyme-induced spheroplasts of E. coli (Hofschneider \& Lorek, 1962). More recently a third variety of Proteus L-forms has been described (Martin, 1964). This type is non-reverting, i.e. stable. It does, however, retain a cell wall, including a fragile, balloon-shaped murein sacculus. Proteus L-forms may thus be classified into three types according to the presence or absence of cell walls and the ability or failure to revert to the bacterial form upon transfer to penicillin-free medium:

(I) A stable protoplast-L-form which is not able to revert; cell walls are absent.

(2) An unstable spheroplast-L-form which is able to revert; cell walls are present.

(3) A stable spheroplast-L-form which does not revert, but cell walls are present.

In the present paper we wish to report additional morphological evidence for the the different organization of surface layers in the three types of Proteus L-forms. Electron microscopy of thin sections shows specific stages of deficiency and disorder in cell walls of different L-forms and provides additional support for the L-form classification listed above.

Although thin sections enable the protoplast- and the spheroplast-types of L-forms to be easily distinguished from each other, they are not so useful for localizing the sites of chemical damage within the cell wall which give rise to L-forms. Selective in situ identification of individual macromolecular cell-wall components is still not possible in the electron microscope, and it is not known how the different polymer constituents contribute to the image of the thin-sectioned enterobacterial cell wall. Therefore we have studied thin sections of isolated cell walls from normal Proteus mirabilis and sections of purified preparations of murein sacculi and lipopolysaccharide. Our findings permit us to draw some conclusions on the location and interaction of wall polymers in normal Proteus cell walls and on the nature and extent of cell wall disorganization in the different Proteus L-forms.

\section{METHODS}

The following L-forms and bacterial strains of Proteus mirabilis were studied:

(I) The unstable spheroplast-L-form, strain ICA/PEN, was isolated in 1955 by Kandler \& Kandler (1956) and re-investigated by Martin (1964). All liquid and solid media in which this organism was cultivated contained Na-benzylpenicillin (Farbwerke Hoechst A. G., Frankfurt/Main-Hoechst) at a concentration of 200 units/ml. Subcultivation of individual spheroplasts of the unstable L-form I CA/PEN on penicillin- 
free medium yielded a wide variety of stable L-forms and bacillary organisms (Martin, 1963, 1964). The following descendants of strain ICA/PEN were included in this study.

(2) Stable spheroplast-L-form, strains I CA/20 and I CA/25.

(3) The rod-shaped, non-motile Proteus mirabilis, strain I CA/5. In addition to this strain normal, rod-shaped $P$. mirabilis, strain vI, was also studied.

(4) Also investigated were the stable protoplast-L-forms, strains LD 52 and LV. These organisms were obtained from Dr U. Taubeneck, Jena. Growth of the protoplast-Lforms required supplementation of the media with $5 \%(\mathrm{v} / \mathrm{v})$ defibrinated horse serum.

Culture medium. All organisms used for electron microscopy and for the preparation of cell walls and cell-wall fractions were grown at $35^{\circ}$ in aerated liquid cultures with the following composition (g./l.): tryptic casein peptone (E. Merck, A. G., Darmstadt), 15; Lab-lemco beef extract (Oxoid Ltd., London S.E. I, England), I5; glucose, 2; $\mathrm{NaCl}, 5 ; \mathrm{Na}_{2} \mathrm{HPO}_{4}, 4 \cdot 5$; distilled water, I 1.; $\mathrm{pH}$ adjusted to $7 \cdot 0$. The cultures were harvested at the beginning of the stationary phase. The isolation of cell walls and the separation and purification of individual polymer cell-wall components, viz. murein sacculi and lipopolysaccharide, was carried out as described by Martin \& Frank (1962) and Martin (1964). An outline of the procedure for the isolation of LPS and murein sacculi is given in Fig. I.

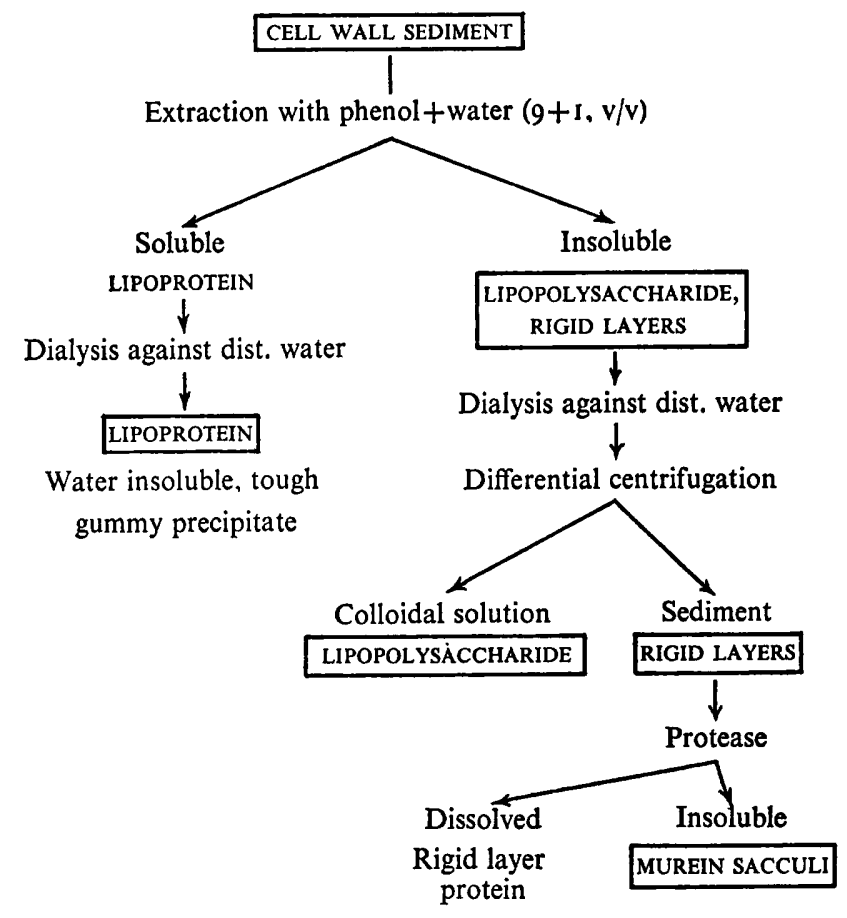

Fig. I Fractionation of isolated cell walls of Proteus mirabilis into the major macromolecular constituents.

Preparation of specimens. For direct electron microscopy samples were mounted on collodion membranes by the agar filtration technique of Kellenberger (1952) and shadowed with a platinum-iridium alloy. Samples for thin-sectioning were pretreated 
in two different ways. Normal bacteria and isolated cell-wall material were fixed with osmium tetroxide (Ryter \& Kellenberger, I958). Potassium bichromate (I \%, w/v) in acetone + water (I/9) was used for the fixation of spheroplasts and protoplasts, since these organisms are easily lysed by osmium tetroxide (Hofschneider, I960). Bacterial cells were treated in parallel by both methods of fixation in order to make sure that the cell integuments were similarly preserved by the different fixatives. The fixed specimens were embedded in Vestopal W (Ryter \& Kellenberger, 1958), sectioned and stained in $0.5 \%(\mathrm{w} / \mathrm{v})$ aqueous uranyl acetate (Hofschneider, 1960$)$ and examined in a Siemens Elmiskop I at an original magnification of $\times 8000$.

\section{RESULTS}

\section{Phase-contrast microscopy.}

This revealed very little difference in gross morphology between the stable protoplastL-form (PI. I, fig. I), the unstable spheroplast-L-form (Pl. I, fig. 2) and the stable spheroplast-L-form (Pl. I, fig. 3). All L-form cultures were assortments of more or less spherical organisms of rather variable size. Reproduction occurred by formation of buds.

\section{Electron microscopy}

\section{Thin sections of bacteria and $L$-forms}

Rod-shaped bacteria, strains Proteus mirabilis VI and I CA/5. A section of the bacterial (rod-shaped) form of Proteus mirabilis is shown in Pl. I, fig. 4, Here, the cell contents are surrounded by two separate and superposed integuments. The inner integument is approximately $80 \AA$ thick and adheres closely to the cytoplasmic cell body. It has the characteristic triple layer structure (electron dense-transparent-dense) of the so-called 'unit membrane' (Robertson, 1959), and thus corresponds to the integument previously described as cytoplasmic membrane in sectioned Escherichia coli (Kellenberger \& Ryter, 1958). In recent years the term 'unit membrane' has come to imply a standard element of micromorphology and also of physico-chemical cell structure and function (viz. the protein-coated bi-molecular lipid leaflet of the cytoplasmic membrane, harbouring the functions of selective permeability and active transport). In the present paper we prefer the strictly morphological term: Triple Layer integument (TLintegument). This describes a bacterial integument having the appearance but not necessarily the structure and function of 'true' unit membranes, as represented by cytoplasmic membranes and related membraneous organelles. This reservation is particularly pertinent for the description of the outer integument of the enterobacterial cell which has been assumed to represent the cell wall in studies on thin sectioned $E$. coli. In sections of $P$. mirabilis strain vI, the outer integument was about I00-I $20 \AA$ thick but otherwise resembled the inner one; it was also a TL-integument, although in some places a third electron-dense layer seemed to be present, bringing the total to five layers: dense-transparent-dense-transparent-dense. Recently, several authors have published micrographs of $E$. coli sections in which three electron-dense layers can be clearly distinguished in the outer integument (Frank \& Dekegel, 1965; Murray, Steed \& Elson, I965; de Petris, 1965; Weibull, 1965). In some cases these structures resemble the familiar picture of two merging unit membranes (Robertson, 1959). Frank \& Dekegel have re-investigated sections of our Proteus strain I CA/5 and VI and have found five-layered outer integuments in some cases (Frank \& Dekegel, 
1967). However, this feature was not consistently observed. Triple-layered outer integuments were found in other cells of the same preparation.

Stable protoplast-L-form, strains $L D 52$ and $L V I$. In sections of strains LD 52 and LVI only one integument was observed, a TL-integument located immediately outside the cytoplasm (Pl. I, fig. 5). The identity of this TL-integument with the cytoplasmic membrane is suggested by its sensitivity to mechanical and osmotic stress and the action of detergent. By osmotic shock of $\mathrm{L}$-form organisms in distilled water separate integuments were obtained as empty 'ghosts'. Metal-shadowed preparations of these structures disintegrated rapidly into smaller fragments or coalesced into larger aggregates under the electron beam. In dilute aqueous solutions of sodium dodecylsulphate $(0.05 \%, w / v)$ the ghosts were instantly dissolved without leaving any particulate residue visible in the electron microscope (Martin, unpublished observations).

Stable spheroplast-L-form, strains ICA/20 (Pl. I, fig. 6) and ICA/25. These organisms were found to have two separate, superposed integuments of virtually identical appearance. Both were TL-integuments of very similar thickness: approximately 80-100 $\AA$. The inner TL-integument was located in the same position as the presumed cytoplasmic membrane of the protoplast-L-form; the outer TL-integument was in a corresponding position to the cell wall of normal Proteus mirabilis cells.

Unstable spheroplast-L-form, strain ICA/PEN, grown in the presence of penicillin (P1. 2, fig. 7a). An outer and an inner integument were observed. Only the inner one was a perfect TL-integument, resembling the 'cytoplasmic membrane' of the other L-forms and the bacterial form. The outer integument (cell wall) showed signs of extensive disorganization; only short, intermittent stretches of TL-integument were preserved, connected by stretches of diffusely contoured single-layer integument. Other cell-wall material was seen in the process of detachment from the outer surface of the cell wall. Massive dissociation of small, globular particles from the outside of the same L-form spheroplasts had been found previously in metal-shadowed preparations (Martin, 1964) and is shown again in P1. 2, fig. $7 b$. In the thin-sectioned L-form preparation (Pl. 2, fig. $7 a$ ) one can see that the surface particles are hollow spherules bordered by single TL-integuments.

Thin sections of isolated cell walls and cell-wall polymers of rod-shaped Proteus bacteria

Cell walls. Thin sections of isolated and thoroughly washed cell walls of Proteus mirabilis, strain ICA/5 (P1. 2, fig. 8), revealed structures resembling well preserved TL-integuments, although the distinct frayed appearance of the two electron-dense layers is atypical. Otherwise, this observation supports the previous conclusions about sections of whole bacteria and spheroplast-L-forms. It should be explained, however, why a sectioned cell wall displays an ultrastructure which is thought to be characteristic for cytoplasmic membranes and related membraneous organelles. One possible explanation, contamination of the isolated cell walls with cytoplasmic membrane matter, seems to be excluded. Cell wall isolation involved vigorous and prolonged shaking of bacteria with glass beads in aqueous suspension containing $0.8 \%(\mathrm{w} / \mathrm{v})$ sodium dodecylsulphate. As cytoplasmic membranes of the stable protoplast-L-form are dissolved instantly by much smaller detergent concentrations, it is unlikely that cytoplasmic membrane residues adhering to the cell wall could have survived the combined mechanical treatment and detergent extraction. 
Cell-wall polymers. Not all of the major polymer components of the enterobacterial cell wall could be isolated in a purified state which is amenable to the thin-sectioning technique. The lipoprotein fraction was obtained as a tough, rubber-like substance, unfit for processing on the ultramicrotome. Useful thin-sections could be prepared from isolated lipopolysaccharide and murein sacculi.

Lipopolysaccharide. In metal-shadowed specimens of Proteus LPS (PI. 2, fig. 9) we saw typical vermiform particles with a tendency to merge into larger platelets, quite in analogy to previously described lipopolysaccharides of a Salmonella species (Schramm, Westphal \& Lüderitz, 1952) and Escherichia coli (Weidel et al. 1960). In thin-sections the LPS-particles were revealed as hollow bags or tubes which were again bordered by TL-integuments (Pl. 3, fig. I0). The spacing and dimensions within the LPS-triple layer were very similar to those found in sections of whole cell walls, with which sections of larger LPS-aggregates might therefore be confused.

Murein sacculi. Isolated murein sacculi of Proteus mirabilis, strain I CA/5 have the well-known appearance of the 'bag-shaped macromolecules' which determine the form of the bacterial cell (Pl. 3, fig. II): In sacculus sections (Pl. 3, fig. I2) the profile of the murein appears as a single electron-dense line with an approximate thickness of 20 to $25 \AA$. The lower value probably applies to those areas where the murein sheet has been cut most nearly at a right angle.

Sections of isolated cell walls after removal of murein with lysozyme. Since it has been shown that sectioned murein and LPS have typical morphological features with definite dimensions, one would now like to know whether or not electron microscopy can tell us something about the position of these substances, relative to each other, within the cell wall. Thus, for instance, it should be possible to localize the site of the murein sacculus by comparing thin-sections of normal isolated cell walls with those of cell walls from which murein has been specifically removed by the action of lysozyme. Isolated cell walls of Proteus mirabilis, strain I CA/5 (50 mg dry weight) were incubated for $16 \mathrm{hr}$ at $37^{\circ}$ in $20 \mathrm{ml} .0 \cdot \mathrm{I} \mathrm{M}$-tris buffer, $\mathrm{pH} \mathrm{7.0}$, containing $300 \mu \mathrm{g}$. crystalline eggwhite lysozyme (Worthington Chem. Co., Freehold, N.J., U.S.A.). Soluble murein fragments were removed from the digested cell walls by four consecutive washings with tris buffer and distilled water and sedimentation of the residual cell walls in the centrifuge at $20,000 \mathrm{~g}$. In thin sections of lysozyme-treated cell walls (Pl. 3, fig. 13) the original cell shape was fairly well preserved. The walls also retained their organization as TL-integuments with virtually the same dimensions as in untreated cell walls. No disappearance of an electron-dense $20 \AA$ layer from the TL-integument could be observed. On the other hand, the enzymic breakdown of the murein sacculus had a very marked effect on the mechanical stability of the cell wall and its sensitivity to the action of detergents. Now, shaking with glass beads for a few seconds caused complete fragmentation, and incubation in a solution of $0.4 \%(w / v)$ sodium dodecylsulphate induced disaggregation of the cell walls into small particles.

\section{DISCUSSION}

Electron microscopy of thin-sectioned Proteus L-forms leaves no doubt that this group of 'cell wall-defective bacteria' (Davis, 1966) contains organisms of the spheroplast-type as well as forms which are virtually indistinguishable from bacterial protoplasts. Concerning the protoplast nature of the stable protoplast L-form our observa- 
tions agree well with the previous reports of Weibull (1965) and Tulasne, Minck \& Kirn (1962). In Proteus the ability to form a cell wall must be closely linked with the ability to construct a murein sacculus. It has been observed earlier that the stable protoplast L-form strains LVI (Martin, I964) and LD52 (Weibull, I965) produce LPS. Moreover, it has been shown that LVI produces functional bacteriophage receptor substances and excretes them into the culture medium (Zickler, 1967), although the L-form-protoplasts themselves are phage-resistant. It must be concluded, that although plastic wall polymers such as LPS and probably also lipoprotein are synthesized by the protoplast L-form, the protoplasts are not able to retain these substances on their surfaces and integrate them into a coherent integument in the absence of murein. In the stable and unstable spheroplast $L$-forms our observations on the presence of cell walls in thin sections agree well with the previous reports on the occurrence of murein and other typical wall materials in these organisms (Kandler et al. 1958; Martin, 1964). But the decreased thickness of the L-form walls and the visible escape of wall material from the spheroplast surface of the unstable L-form indicate that here the plastic wall polymers cannot be as tightly bound to their murein base as in the normal bacterial form. We know from previous studies that the LPS content of cell walls decreases from $42 \%$ in normal $P$. mirabilis, strain VI, to $24 \%$ in the stable spheroplast-L-form, strain I CA/25, and II \% in the unstable spheroplast-L-form, strain I CA/PEN (Martin, 1963). The loose adhesion of the plastic wall polymers may be largely due to the defective architecture of the murein sacculi in spheroplast-L-forms (Martin, 1964, 1967). However, another explanation is also possible. It has been shown that the component of the enterobacterial cell wall which determines shape does not exist in the form of a simple murein sacculus, but rather as a so-called 'rigid layer', a covalently interlinked complex of a murein sacculus and protein. In 'rigid layers' of normal, rod-shaped Escherichia coli and Proteus mirabilis the protein is attached to the surface of the sacculi as a multitude of tuft-like appendages, giving the appearance, under the electron microscope, of a regular, granular surface layer (Weidel et al. 1960; Martin, 1964). Recent observations by Fishman \& Weinbaum (1967) on negatively stained $E$. coli walls suggest that rigid-layer protein is even more regularly attached to the murein sacculus than has so far been suspected. In contrast, the rigid layer equivalents of the L-form cell walls lack this regular arrangement of the protein component. In the heavily damaged structures, which in the unstable spheroplast L-form correspond to the rigid layer, the protein content is also greatly reduced (Martin, 1964).

One might assume that rigid layer protein normally serves to attach lipoprotein and lipopolysaccharide to the cell wall. In its disorganized state in the L-form cell wall it may no longer be able to fulfil this function. A similar interpretation might also apply to the recently reported spontaneous dissociation of LPS from the cell walls of a lysinerequiring Escherichia coli mutant (Knox, Vesk \& Work, 1966). In summary, we should like to propose a schematic view of the profile of a normal enterobacterial cell wall (Fig. 2), and its state in the unstable spheroplast L-form of Proteus mirabilis (Fig. 3). These models also take into account the previous studies on the composition of the cell wall of E. coli B (Weidel, Koch \& Lohss, 1954; Weidel, Koch \& Bobosch, I954; Weidel \& Kellenberger, 1955; Weidel, 1958; Weidel et al. 1960). This work has shown that lipoprotein and lipopolysaccharide are deposited on the outer surface of the ' rigid layer', making the murein sacculus within the intact cell-wall complex inaccessible to the attack of lytic enzymes from without. Both lipoprotein and LPS display their 
functions as antigens and bacteriophage receptors on the cell surface. However, quantitative phage receptor tests have shown that a large part of potential receptor sites in the lipopolysaccharide (for phages $\mathrm{T}_{3}, \mathrm{~T}_{4}$, and $\mathrm{T}_{7}$ ) are masked, probably by partially superposed lipoprotein. Plastic wall polymers have been extracted from the cell wall of $E$. coli B in the form of minute globules displaying specific receptor function for bacteriophage $\mathrm{T} 5$. In these isolated receptor particles LPS has been found to form the core and lipoprotein the superposed surface coating. More recently, T 5receptor particles have been studied as thin sections and have been shown to be hollow

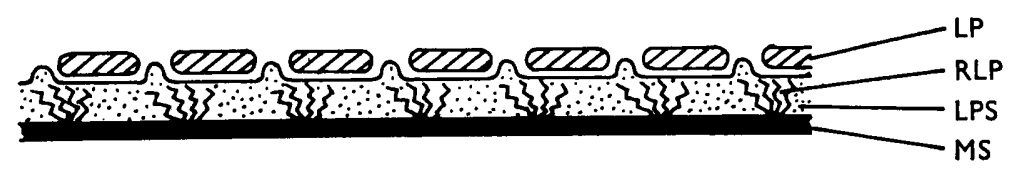

Fig. 2. Schematic view of cross-sectioned cell wall of normal rod-shaped Proteus mirabilis. $\mathbf{L P}=$ lipoprotein $;$ LPS = lipopolysaccharide; $\mathbf{M S}=$ murein sacculus $; \mathbf{R L P}=$ rigid layer protein. Explanation in text.

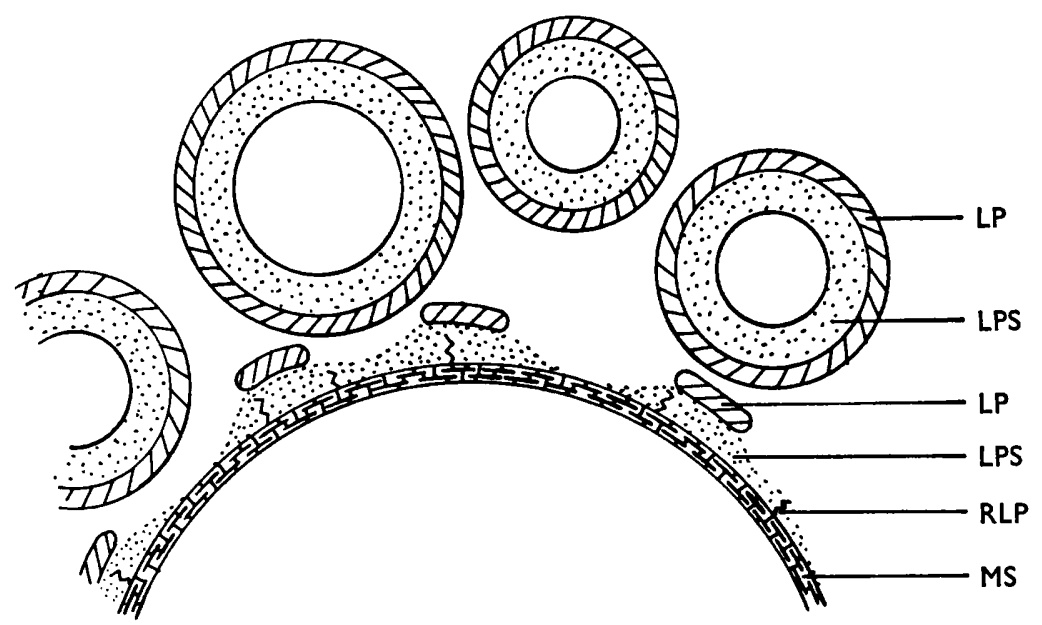

Fig. 3. Cross-section of the damaged cell wall of unstable L-form spheroplast, schematic view Abbreviations as in Fig. 2. Reduced stability of the murein sacculus and extensive loss of rigid layer protein allow the plastic wall material LP and LPS to leave the cell wall in the form of hollow spherical particles.

bags surrounded by TL-integument (Frank \& Dekegel, 1965, 1967). The sections of T 5-receptor closely resemble those of the spherules which are liberated spontaneously from the spheroplast surface of the unstable Proteus spheroplast-L-form. The TLinteguments of both of these surface particles are indistinguishable from the TLintegument of isolated LPS from $E$. coli (Frank \& Dekegel, 1965, 1967) and $P$. mirabilis. Our studies and those of Frank \& Dekegel (1965, 1967) have shown clearly that two of the major constituents of enterobacterial cell walls, LPS and murein, have well-defined morphological properties when sectioned and viewed as isolated preparations. However, these observations are still of limited value for establishing the sites and space requirements of LPS and murein in the intact cell wall. When sections of intact isolated cell walls and LPS are compared, it is obvious that much, if not most, of 
the cell wall image is contributed by the LPS alone. Some, but certainly not all, of the lipoprotein may have been dissolved during the isolation of cell by the mechanical treatment and detergent extraction. Even so, one cannot localize the residual lipoprotein and the rigid-layer in the TL-integument of the cell-wall section. Therefore it seems necessary to conclude that it is not possible with the techniques now available to identify the lipoprotein and the rigid layer within sectioned cell walls as structures distinct from the LPS. Other questions must also be left unanswered. Thus, the basis for the TL-integument formation by the macromolecular LPS is far from clear. The structural principle could hardly be the same as in the formation of the bi-molecular leaflet from low-molecular weight lipid molecules in cytoplasmic membranes. Cell walls of enteric bacteria (just as those of Gram-positive bacteria) have been found to act as molecular sieves (Lieve, I965 $a, b$; Polsinelli, Ciferri, Cassani \& Albertini, I964), but they are not known to have properties of selective permeability similar to those of cytoplasmic membranes. On the contrary, in thin sections of plasmolysed $E$. coli as in plant cells, it can be seen that the cell content within the cytoplasmic membrane decreases in size and recedes from the cell wall which retains its normal size and shape (Cota-Robles, 1963). In the studies of Frank \& Dekegel $(1965,1967)$ and also in our work the thickness of sectioned murein sacculi in $E$. coli and in $P$. mirabilis has been determined at 20-25 $\AA$. If these values should prove to be correct they would lend support to the recently proposed assumption that murein sacculi of enterobacterial cell wall are monolayers of murein (Weidel \& Pelzer, 1964).

We are greatly indebted to Professors A. Butenandt and O. Kandler for their generous support and continued interest in this work. The capable and diligent assistance of Miss Anneliese Preuss in the electron microscopical work is gladly acknowledged. Our study was supported by grants of the Deutsche Forschungsgemeinschaft to H. H. Martin and P. H. Hofschneider.

\section{REFERENCES}

Cota-Robles, E. H. (I963). Electron microscopy of plasmolysis in Escherichia coli. J. Bact. 85, 549. Davis, B. D. (1966). Proposal made at 'Brook Lodge Conference on Microbial Protoplasts, Spheroplasts and L-forms', Augusta, Mich., U.S.A.

Fishman, D. A. \& Weinbaum, G. (1967). Hexagonal pattern in cell walls of Escherichia coli B. Science, N.Y. I55, 472.

Frank, H. \& Dekegel, D. (1965). Zur Interpretation von Zellwand-Strukturen in Dünnschnitten Gram-negativer Bakterien. Zentbl. Bakt Abt., I, r98, 81.

FrANK, H. \& DeKEGEL, D. (1967). Electron microscopical studies on the localization of the different components of cell walls of Gram-negative bacteria. Folia microbiol., Praha 12, 22 I.

HofSCHNeIDER, P. H. (1960). Zur Wandstruktur von Escherichia coli B Sphaeroplasten. Proc. Eur. Reg. Conf. Electron Microscopy, Delft., vol. 2, 1028.

HofsChNeider, P. H. \& LoREK, H. (1962). Studies on the residual cell wall structures of E. coli and B. megaterium spheroplasts and of L-forms of Proteus mirabilis. Proc. 5th int. Congr. Electron Microscopy, Philadelphia, RR9.

KANDLER, O. \& KANDLER, G. (1956). Trennung und Charakterisierung verschiedener L-Phasen-Typen von Proteus vulgaris. Z. Naturf. II $b, 252$.

KANDLER, O. \& ZEHENDER, C. (I957). Über das Vorkommen von $\alpha$, $\epsilon$-Diaminopimelinsäure bei verschiedenen L-Phasentypen von Proteus vulgaris und bei den pleuropneumonieähnlichen Organismen. Z. Naturf. $12 b, 725$.

KANDler, O., Hund, A. \& Zehender, C. (1958). Cell wall composition in bacterial and L-forms of Proteus vulgaris. Nature, Lond. 181, 572. 
Kellenberger, E. (I952). Die Einflüsse verschiedener Präparationsmethoden auf E. coli B. Z. wiss. Mikrosk. 60, 408.

Kellenberger, E. \& RYTER, A. (1958). Cell wall and cytoplasmic membrane of Escherichia coli. J. biophys. biochem. Cytol. 4, 323.

KLIENEBERGer-Nobel, E. (1960). L-forms of Bacteria. In The Bacteria. Ed. by I. C. Gunsalus and R. Y. Stanier. Vol. 1, p. 363. New York and London: Academic Press.

KNOX, K. W., VESK, M. \& WORK, E. (1966). Relation between excreted lipopolysaccharide complexes and surface structures of a lysine limited culture of Escherichia coli. J. Bact. 92, I 206.

LIEVE, L. (1965a). Release of lipopolysaccharide by EDTA treatment of E. coli. Biochem. biophys. Res. Comm. 2I, 290.

LIEVE, L. (1965b). Actinomycin sensitivity in Escherichia coli produced by EDTA. Biochem. biophys. Res. Comm. 18, I3.

Martin, H. H. (1963). Über den Aufbau der Zellwand bei Bakterien und L-Formen von Proteus mirabilis. Habilitationsschrift; Technische Hochschule München.

Martin, H. H. (1964). Composition of the mucopolymer in cell walls of the unstable and stable L-form of Proteus mirabilis. J. gen. Microbiol. 36, 44I.

Martin, H. H. (1967). Murein structure in cell walls of normal bacteria and L-forms of Proteus mirabilis and the site of action of penicillin. Folia microbiol., Praha 12, 234.

Martin, H. H. \& Frank, H. (1962). Quantitative Bausteinanalyse der Stützmembran in der Zellwand von Escherichia coli $\mathbf{B}$. $Z$. Naturf, $\mathbf{1 7} b, 190$.

Murray, R. G. E., Steed, P. \& Elson, H. E. (1965). The location of the mucopetide in sections of the cell wall of Escherichia coli and other Gram-negative bacteria. Can. J. Microbiol. II, 547.

DE PeTris, S. (1965). Ultrastructure of the cell wall of Escherichia coli. J. Ultrastructure Res. 12, 247.

Polsinelli, M., Ciferri, O., Cassani, G. \& Albertini, A. (1964). Mechanism of resistance to actinomycin in Bacillus subtilis. J. Bact. 88, 1567.

Robertson, I. D. (1959). The ultrastructure of cell membranes. Symp. Biochem. Soc. 16, 3.

RYTer, A. \& Kellenberger, E. (1958). Les nucléoides des bactéries en croissance active. $Z$. Naturf. $\mathbf{r 3} b, 597$.

Schramm, G., Westrhal, O. \& LÜderitz, O .(1952). Über bakterielle Reizstoffe. III. Physikalischchemisches Verhalten eines hochgereinigten Coli-Pyrogens. Z. Naturf. $7 b, 594$.

TAUBEneCK, U. (196I). Die Phagenresistenz der stabilen L-Form von Proteus mirabilis. Z. Naturf. 16 , 849.

Taubeneck, U., Böhme, H. \& Schumann, G. (1958). Untersuchungen über die L-Phase von Proteus mirabilis mit Hilfe von Bacteriophagen. Biol. Zbl. 77, 663.

Tulasne, R., Minck, R. \& KIRN, A. (1962). Étude comparative, au microscope électronique, d'un Proteus et des formes $\mathrm{L}$ des types A et B corréspondantes. Annls Inst. Pasteur, Paris ro2, 292.

WeIBulL, C. (1965). Structure of bacterial L-forms and their parent bacteria. J. Bact. 90, 1467.

WeIDEl, W. (1958). Bacterial viruses. A. Rev. Microbiol. 12, 27.

Weidel, W. \& Kellenberger, E. (1955). The E. coli B-receptor for the phage T 5. II. Electron microscopic studies. Biochim. biophys. Acta 17, I.

Weidel, W. \& Pelzer, H. (1964). Bag-shaped macromolecules-a new outlook on bacterial cell walls. Adv. Enzymol. 26, 193.

Weidel, W., Frank, H. \& Martin, H. H. (1960). The rigid layer of the cell wall of Escherichia coli strain B. J. gen. Microbiol. 22, 158.

WeIDel, W., Косн, G. \& ВовозсH, K. (1954). Über die Rezeptorsubstanz für den Phagen T 5. I. Extraktion und Reindarstellung aus E. coli B., Z. Naturf. $9 b, 573$.

WeIDel, W., Koch, G. \& Lohss, F. (1954). Über die Zellmembran von E. coli B. II. Der Rezeptorkomplex für die Bakteriophagen $\mathrm{T}_{3}, \mathrm{~T}_{4}$ and $\mathrm{T}_{7} . Z$. Naturf. $9 b, 398$.

ZICKLER, F. (1967). Phagenrezeptorsynthese durch die stabile L-Form von Proteus mirabilis VI. Z. allg. Mikrobiol. 7283. 
Journal of General Microbiology, Vol. 5I, No. I

Plate I
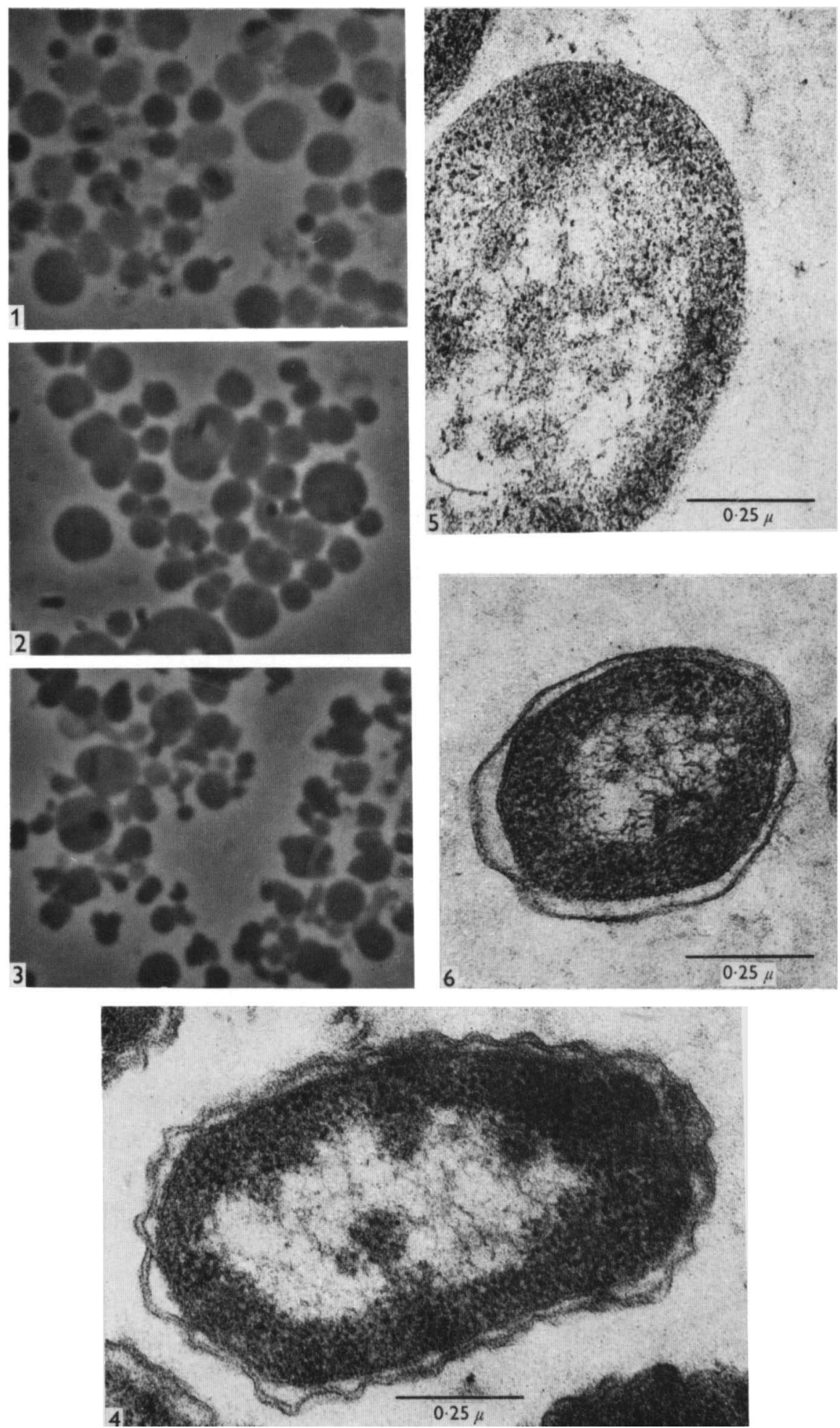

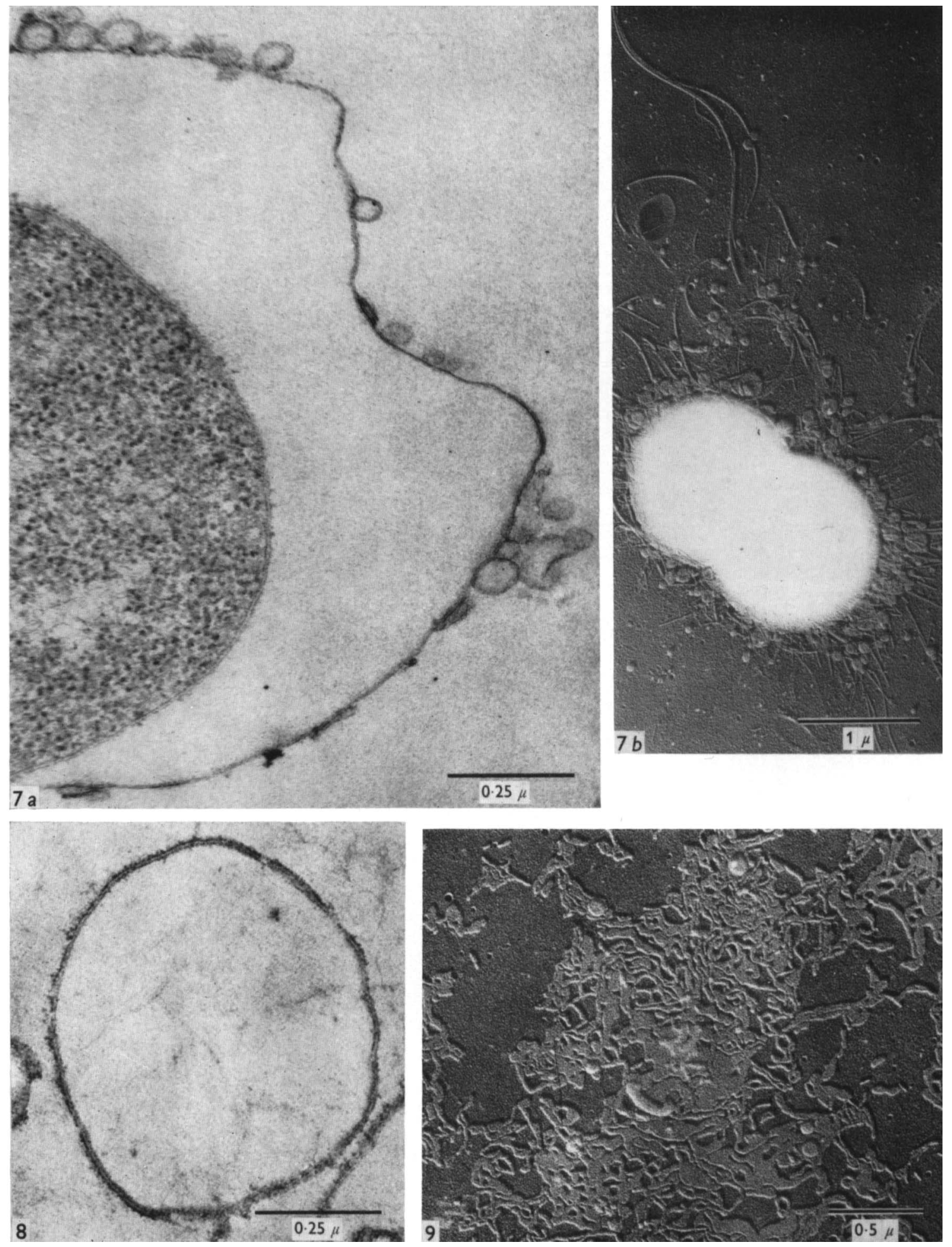
Journal of General Microbiology, Vol. 5I, No. I

Plate 3
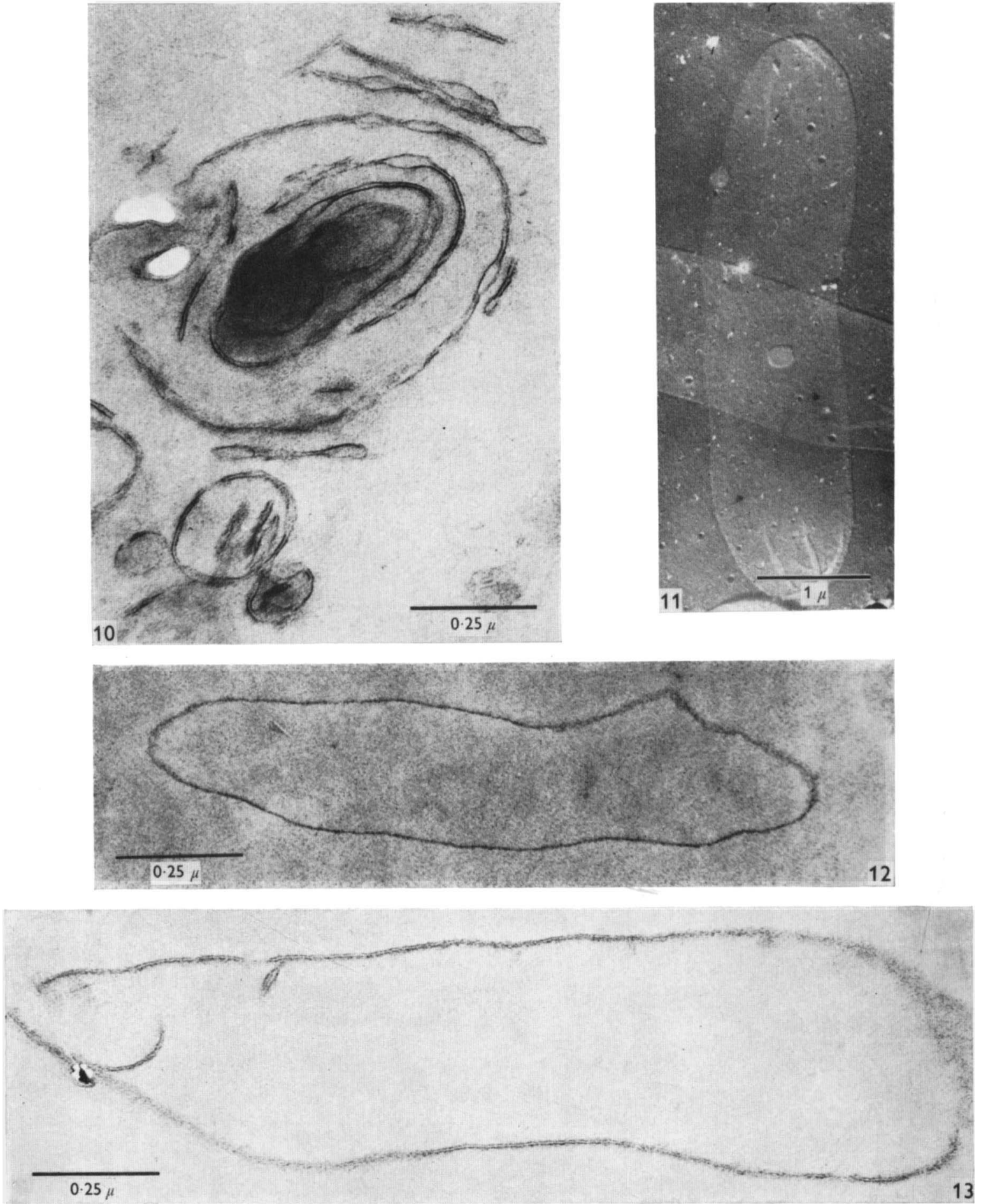
EXPLANATION OF PLATES

Plate I

Fig. I. Stable protoplast L-form of Proteus mirabilis, strain LD 52; phase-contrast. $\times 3600$.

Fig. 2. Unstable spheroplast L-form of Proteus mirabilis, strain I CA/PEN; phase-contrast. $\times 3600$.

Fig. 3. Stable spheroplast L-form of $P$. mirabilis, strain I CA/20; phase-contrast. $\times 3600$.

Fig. 4. Section of rod-shaped $P$. mirabilis, strain vi. $\times 80,000$.

Fig. 5. Section of stable protoplast L-form, strain LD 52. $\times 80,000$.

Fig. 6. Section of stable spheroplast L-form, strain I CA/20. $\times 80,000$.

\section{Plate 2}

Fig. 7. Unstable spheroplast L-form, strain I CA/PEN: $(a)$ section of L-form spheroplast. $\times 80,000$ (b) Pt-Ir-shadowed L-form spheroplast in the process of division. $\times 19,300$.

Fig. 8. Section of isolated cell wall of rod-shaped $P$. mirabilis, strain $\mathrm{ICA} / 5 . \times 80,000$.

Fig. 9. Lipopolysaccharide, isolated from cell walls of $P$. mirabilis, strain ICA/5. Pt-Ir-shadowed. $\times 30,000$.

\section{Plate 3}

Fig. Io. Section of isolated lipopolysaccharide. $\times 80,000$.

Fig. I I. Murein sacculus, isolated from cell wall of $P$. mirabilis, strain I CA/5. Pt-Ir-shadowed. $\times 18,000$.

Fig. 12. Section of isolated murein sacculi of $P$. mirabilis, strain $\mathrm{ICA} / 5 . \times 80,000$.

Fig. 13. Section of isolated cell wall of rod-shaped P. mirabilis, strain I CA/5, after removal of murein by lysozyme treatment. $\times 80,000$.

The bars on Pl. I, figs. 4-6, Pl. 2, figs. $7 a$ and 8 and Pl. 3, figs. IO, I 2 and $\mathrm{I} 3$ represent $0.25 \mu$. The bar on Pl. 2, fig. 9 represents $0.5 \mu$. The bars on Pl. 2, fig. $7 b$ and Pl. 3, fig. I I represent I $\mu$. 